Agro-Science Journal of Tropical Agriculture, Food, Environment and Extension Volume 10 Number 3 September 2011 nn $49-54$

ISSN 1119-7455

\title{
PATHOGENICITY OF FUNGI ASSOCIATED WITH THE COCOYAM ROOT ROT BLIGHT COMPLEX IN SOUTH-EASTERN NIGERIA.
}

\author{
Wokocha, R. C. and Aduo, B. C. \\ Dept. of Plant Health Management, Michael Okpara University of Agriculture, \\ Umudike, P.M.B. 7267, Umuahia Abia State, Nigeria
}

\begin{abstract}
Disease surveys were carried out in major cocoyam (Xanthosoma sagittifolium (L) Schott) growing communities of Igbariam, Lowa and Umudike in the humid tropics of South-eastern Nigeria in 2009 and 2010 cropping seasons. The highest mean disease incidence of $46.7 \%$ and severity of 2.85 occurred in Lowa while the lowest figures of $33.3 \%$ and 2.33, respectively were recorded in Umudike. Isolations of associated fungi made from infected cocoyam root tissues and rhizosphere soils yielded eight different fungal isolates. These were Aspergillus niger Thom and Raper, Botryodiplodia theobromae Pat., Fusarium solani (Mart.) Sacc., Pythium myriotylum Dresch., Rhizoctonia solani Kuhn, Rhizopus nigricans Ehhrenb., Trichoderma harzianum Rifai and Sclerotium rolfsii Sacc. The results showed that P. myriotylum was the most frequently isolated organism in infected cocoyam roots in the three locations with percentage frequency of occurrence of $82-90 \%$ and $60-72 \%$ abundance in infected soils. Pathogencity tests on susceptible cocoyam variety - Xanthosoma sagittifolium $\mathrm{cv}$ ede ocha (NXS001), using all fungal isolates, showed that only $P$. myriotylum was pathogenic on the test crop. The results of this investigation showed that the cocoyam root rot disease was incited by a single organism viz: Pythium myriotylum and not by a complex of organisms as suggested by earlier workers.
\end{abstract}

Keywords: Cocoyam root rot blight complex; cocoyam root rot disease; Pythium myriotylum, Cocoyam, Xanthosoma sagittifolium

\section{INTRODUCTION}

Cocoyam (Xanthosoma sagittifolium (L) Schott) is an important tropical root crop cultivated in rural parts of America, the Caribbeans, the Pacific and West Africa (Arene and Ene, 1987; Tambong et al 1999). It is a herbaceous monocotyledonous plant of the family Araceae, characterized by the presence of underground stem (corm), net-veined, palmately divided broad leaves with long petiole, spadix inflorescence and superficial but fibrous root system (Purseglove, 1972; Dutta, 2005).

Cocoyam is primarily adapted to moist environment. The Mean annual temperature for its cultivation is about $24^{\circ} \mathrm{C}$ with variations ranging from $13^{\circ} \mathrm{C}$ to $29^{\circ} \mathrm{C}$ (Kay, 1987). Optimal yield takes place in deep well drained rich soils with $\mathrm{pH}$ of 5.5-6.5 (Arene and Ene, 1987 and Adiobo et al., 2007). Nigeria is the largest producer of cocoyam in the world with estimated annual production of 5.45 million metric tons (FAO, 2007). Cocoyam is grown popularly in the south-eastern Nigeria. Cocoyam has become an endangered crop on the verge of extinction in the last four decades. One reason for this is that it yields low financial returns and so there is the notion that it is a poor man's crop (Mbanaso et al., 2008). But cocoyam corms and cormels are rich sources of carbohydrate. The protein content is higher in total essential amino acids and the suphur bearing amino acids than other staple foods such as yam, cassava, etc. (Kay, 1987).

Cocoyam production in Nigeria dropped by $11 \%$ between $2000-2004$ due to several field and storage diseases (FAO, 2001; FAO 2004) Fungal diseases of cocoyam include Cocoyam Corm Rot incited by Sclerotium rolfsii, White Leaf spot caused by Leptospharulina trifolli and Anthracnose disease caused by colletotrichum gloeosporiodes. The most important fungal disease of cocoyam (Xanthosoma spp.) is the Cocoyam Root Rot Disease (Pacumbaba et al 1992, Tambong et al 1999). Other cocoyam diseases include bacterial 
leaf spot or blight caused by Xanthomonas campertris $\mathrm{pv}$ aracearum and $X$. axonopodis $\mathrm{pv}$ dieffenbachiae. Insect pest and Nematodes attack growing tubers while viral diseases of cocoyam result in leaf distortion, vein chlorosis but not in Africa (Adiobo et al 2007). The cocoyam root rot disease was reported by Okeke (1982) and Arene and Ene (1987) as caused by a complex of organisms viz: Botryodiphodia theobormae, Fusarium, solani, Rhizoctonia solani,Fusrium moniliforme, Sclerotium rolfsii, Pythium spp and Phytopthora spp.Characteristic symptoms of cocoyam root rot disease include premature leaf yellowing, reduced leaf size and numbers, root decay, root pruning and severe reduction of the root system (Tambong et al 1999). According to Pacumbaba et al (1992) severe infection of Pythium myriotylum incited the root rot disease and resulted in yield reduction as high as $90 \%$ in Cameroon. The etiology of the disease in Nigeria has, however, remained uncertain. Earlier workers (Okeke, 1982; Arene and Ene 1987 and Mbanaso et al 2008) have identified the disease as cocoyam root rot blight complex (CRBC) caused by a number of organisms. The objective of this study was to isolate and identify fungi associated with the cocoyam root rot disease and to determine the pathogenicity of these fungi on cocoyam.

\section{MATERIALS AND METHODS}

Disease surreys were carried out on naturally infected farmers' fields in three locations in major cocoyam growing areas in the humid tropics of south-eastern Nigeria. These locations were: Umudike (Abia State), Lowa (Imo State) and Igbariam (Anambra State). South-eastern Nigeria $\left(04^{\circ} 15^{\prime} \mathrm{N}-07^{\circ} 00^{\prime} \mathrm{N}, 05^{\circ}\right.$ 34'E - 09 24'E; Alt.122 MSL, Unamma et al., 1985). It has mean annual temperatures of $27-$ $32^{\circ} \mathrm{C}$, and mean annual rainfall $1,600 \mathrm{~mm}-$ $4,338 \mathrm{~mm}$. The soil type is tropical ultisol, with $\mathrm{pH}$ of 5.0-6.5 (NRCRI, 2011).

\section{Disease Survey}

A total of five farms each $20 \times 50$ sq. m in size within each location were surveyed during the wet season (June - September) of 2009 and 2010. In the farms, two diagonal transects were taken across and cocoyam plants on every one meter distance along the transect were sample for disease occurrence according to Umechuruba and Elenwo (1997). Disease assessment was carried out visually by noting characteristic symptoms. Disease incidence on a particular field was estimated by counting the number of plants infected within the sampled area of the field and expressing this figure as a percentage of the total number of plants sampled;

Disease incidence $=\underline{\text { No. of infected plants }}$

Total No. of plants sampled 1

Disease severity in each field was assessed by giving each diseased plant a numerical rating similar to that used by Wokocha and Nwaogu (2008) thus:

2

$$
\begin{array}{ccc} 
& 1=1-20 \% \text { of plants infected } \\
3 & 21-39 \% \text { of plants infected } \\
4 & = & 40-50 \% \text { of plants } \\
& = & \begin{array}{l}
\text { infected } \\
\text { infected }
\end{array} \\
5 & = & \begin{array}{l}
70 \% \text { of plants } \\
\text { infected. }
\end{array}
\end{array}
$$

\section{Collection And Handling Of Field Samples From Diseased Cocoyam roots}

A total of five infected cocoyam plants randomly selected from each field were carefully dug up (with a clean spade), placed in separate clean specimen bags and taken to the laboratory for analysis. The materials were stored briefly in the refrigerator before use.

\section{From the soil.}

Before collection of soil sample, the top $6 \mathrm{~mm}$ of soil around the infected cocoyam plants was cleared to remove organic debris. With a clean trowel, about $100 \mathrm{~g}$ of the infected rhizosphere soil was removed at a depth of $6 \mathrm{~cm}$ and placed inside a clean polyethylene bag and carried to the laboratory for analysis.

Five soil samples from each field were bulked together and air-dried inside a sterile tray covered with muslin cloth for 12 hours. Dried samples were temporarily stored in the refrigerator before use.

\section{Isolation Of Associated Fungi \\ Isolation from infected cocoyam roots.}

Infected roots were freed from soil by washing in sterile water to remove soil particles and other debris. The washed roots were cut with sterile scalpel into sections $3-5 \mathrm{~cm}$ long, surface disinfected in $1 \%$ commercial bleach (sodium hypochlorite for 30 seconds, rinsed in three changes of distilled water and dried between sheets of sterile filter paper. The root sections were plated on fresh potato dextrose agar (PDA) in $9.00 \mathrm{~cm}$ Petri dishes. The dishes were incubated at $28 \pm 2^{\mathrm{oC}}$ for five days. Pure cultures of the isolates were obtained by successive subculturing on PDA medium and stored as stock cultures on PDA slants inside McCartney bottles in the refrigerator at $15^{\circ} \mathrm{C}$. 


\section{Isolations from Rhizosphere Soil Sample}

One gram of the bulked soil sample was weighed out and mixed with $9 \mathrm{ml}$ of sterile distilled water in a test tube and the suspension shaken together manually for 10 minutes before allowed to settle. From this stock a ten fold serial dilution was made by transferring $1 \mathrm{ml}$ of the suspension into a blank $9 \mathrm{ml}$ of sterile distilled water until a concentration of $10^{-3}$ was obtained according to Martin (1991). One milliliter of this soil suspension was aseptically transferred into a sterile Petri dish before $15 \mathrm{ml}$ of molten PDA medium was poured into the dish. The mixture was gently swirled to achieve even dispersion of soil particles. The plates were incubated at $28 \pm 2^{\circ} \mathrm{C}$ for five days. Pure cultures of the fungal isolates were obtained by subculturing into sterile PDA plates and preserved inside PDA slants in McCartney bottles in the refrigerator at $15^{\circ} \mathrm{C}$.

\section{Microscopic Examination And Identification Of Fungal Isolates}

Wet mounts of pure cultures were viewed under a binocular compound microscope at X40 magnification. Identification of the isolates was made by reference to $\mathrm{CMI}$ Description of Pathogenic Fungi and Bacteria, Compendium of Soil Fungi (Waterhouse and Waterson, 1966) and Barnet and Hunters, (1987).

\section{Soil sterilization.}

Soil used in this experiment was garden soil collected from the National Root Crops Research Institute (NRCRI) research farm, Umudike. The soil was heat-sterilized in a cut metal drum heated with firewood at $100^{\circ} \mathrm{C}$ for 3 hours covered and allowed to cool for 12 hours. The sterilized soil was dispensed into $30 \mathrm{~cm}$ diameter plastic pots and wooden trays $-0.5^{\prime} \mathrm{x}$ $3^{\prime} \times 5^{\prime}$ in size. These trays were used as cocoyam seedling nursery

\section{Multiplication of cocoyam seedlings.}

Healthy cocoyam (Xanthosoma sagittifolium cv. ede ocha (NXS001) cormels obtained from the Umuahia main market were used. The cormels were first surface disinfected by immersion in $1 \%$ commercial bleach (sodium hypochlorite) for 5 minutes and then rinsed in three changes of sterile water before being used. The cormels were planted in the wooden trays at the rate of 30 cormels per tray and watered daily for two weeks to achieve uniform sprouting.

\section{Preparation of inoculum suspension.}

Fungal inocula used in inoculations in this experiment were prepared

according to Wokocha et al (1986). With sterile spatula the fungal mycelia of ten plates of 5-7 day old PDA cultures of each fungai isolates grown at $28 \pm 2^{\circ} \mathrm{C}$ were carefully scrapped into a Waring blender. The materials were blended in $200 \mathrm{ml}$ of sterile distilled water and homogenized for one minute at low speed. The resultant suspension of each inoculum was filtered through three layers of muslin cloth. The fungal mat remaining on each filter was washed in several changes of sterile distilled water to remove traces of stalling material. The population of spore and hyphal bits was determined using Hawskley haemocytometer and a tally counter.

\section{Green House Experiment}

Experiments were conducted in the Plant Pathology greenhouse of the National Root Crops Research Institute, Umudike under the mean temperature of $28^{\circ} \mathrm{C}$ and relative humidity of $70 \%$.

\section{Cocoyam seedling transplant and inoculation in pathogenicity test.}

Four-week old cocoyam seedlings from the nursery trays were transplanted into $30 \mathrm{~cm}$ plastic pots at the rate of one seedling per pot. Seedlings were inoculated seven days after transplanting. Just before inoculation, soil around each seedling was gently removed to a depth of $5 \mathrm{~cm}$, and $100 \mathrm{ml}$ of each fungal suspension was introduced into the opening and the removed soil replaced. Seedlings in the control pots were similarly treated with $100 \mathrm{ml}$ of sterile distilled water. The seedlings were watered daily and observations made over a period of 14 days. The experiment was laid out in a simple completely randomized design (CRD) replicated 3 times.

\section{Statistical Analysis.}

In the analysis of data, reference was made to Obi (1995). Data were then subjected to analysis of variance (ANOVA) using Genstat Discovery Edition 3 and treatment means were compared by using Fisher's Least Significance difference (LSD) at $5 \%$ level of significance. 


\section{RESULTS AND DISCUSSIONS}

Results (Table 1) show that the highest mean disease incidence and severity of $46.7 \%$ and 2.85 were recorded for cocoyam in Lowa respectively and lowest disease figures of $33.3 \%$ and 2.33 respectively occurred in Umudike. No significant $(\mathrm{P}>0.05)$ difference occurred among the disease figures in the three locations (Lowa, Igbariam and Umudike) in the 2009 and 2010 cropping seasons. The high disease incidence in Lowa could be due to the marshy wetlands which exist in the area during most of the rainy season. Waterhouse and Waterson (1966) observed that Pythium spp incited root rot diseases with heavy losses under excessive waterlogged conditions with reduced oxygen levels. The sampled locations in the Southeastern Nigeria have similar environmental conditions enabling the development of cocoyam root rot disease. Adiobo et al., (2007) reported differing cocoyam root rot disease incidences and severity in some soil types in Cameroon.

Table 1: Mean disease incidence and severity of the cocoyam root rot disease on rainfed cocoyam in three locations in South-eastern Nigeria during two successive years: 2009 and 2010.

\begin{tabular}{lllll}
\hline & & $\mathbf{2 0 0 9}$ & $\mathbf{2 0 1 0}$ \\
\hline Location & *D.1(\%) & *D. Severity & D.1(\%) & D. Severity \\
Lowa & 42.5 & 2.40 & 46.7 & 2.85 \\
Igbariam & 33.7 & 1.97 & 39.1 & 2.47 \\
Umudike & 33.5 & 1.83 & 33.3 & 2.33 \\
Grand Mean & 36.6 & 2.07 & 39.7 & 2.55 \\
LSD & 24.18 & 0.776 & 25.22 & 1.122 \\
P & NS & NS & NS & NS \\
\hline D.I. = Disease Incidence & & &
\end{tabular}

* D.S. = Disease Severity

Table 2: Fungi associated with the cocoyam root rot disease (CRRD) in Igbariam, Lowa and Umudike in South-eastern Nigeria and their percentage frequencies of ccurrence.

\begin{tabular}{|c|c|c|c|c|c|c|}
\hline & & & Fungi & & \multicolumn{2}{|r|}{ Location } \\
\hline & \multicolumn{2}{|c|}{ Igbariam } & \multicolumn{2}{|c|}{ Lowa } & & mudike \\
\hline & Root & Soil & Root & Soil & Root & Soil \\
\hline Aspergillus niger & - & $66 \%$ & - & $60 \%$ & - & $52 \%$ \\
\hline Botryodiplodia theobromae & - & $58 \%$ & - & & - & - \\
\hline Fusarium solani & $40 \%$ & $64 \%$ & $62 \%$ & $38 \%$ & $72 \%$ & - \\
\hline Pythium myriotylum & $82 \%$ & $62 \%$ & $90 \%$ & $60 \%$ & $88 \%$ & $72 \%$ \\
\hline Rhizoctonia solani & $30 \%$ & $64 \%$ & - & $60 \%$ & - & $55 \%$ \\
\hline Rhizopus nigricans & - & $67 \%$ & - & $72 \%$ & - & $60 \%$ \\
\hline Sclerotium rolfsii & - & $80 \%$ & - & $72 \%$ & . & $80 \%$ \\
\hline Trichoderma harzianum & - & $70 \%$ & - & $70 \%$ & - & $75 \%$ \\
\hline
\end{tabular}

Table 3 The pathogenicity of eight fungi associated with the cocoyam root rot disease on seedlings of cocoyam (Xanthosoma sagittifolium cv. ede ocha (NXS001) in the greenhouse at temperature of $28 \pm 20 c$ and relative humidity of $70 \pm 10 \%$.

\begin{tabular}{lll}
\hline & & \\
\hline Fungi & Incidence (\%) & Severity \\
Aspergillus niger & Non pathogenic & Non pathogenic \\
Botryodiplodia theobromae & Non pathogenic & Non pathogenic \\
Fusarium solani & Non pathogenic & Non pathogenic \\
Pythium myriotylum & Pathogenic (75\%) & Pathogenic (5\%) \\
Rhizoctonia solani & Non pathogenic & Non pathogenic \\
Rhizopus nigricans & Non pathogenic & Non pathogenic \\
Sclerotium rolfsii & Non pathogenic & Non pathogenic \\
Trichoderma harzianum & Non pathogenic & Non pathogenic \\
\hline
\end{tabular}


A total of eight different fungi were isolated from infected cocoyam root tissues and rhizosphere soils from the three locations (Table 2). These were Aspergillus niger Thom and Raper, Botryodiplodia theobromae Pat., Fusarium solani (Mart.) Sacc., Pythium myriotylum Dresch., Rhizoctonia solani Kuhn, Rhizopus nigricans Ehhrenb., Sclerotium rolfsii Sacc. and Trichoderma harzianum Rifai. In all the locations, a higher percentage (52-80) of the isolates were obtained from soil than from infected root samples (30-90\%). All fungi isolated from the roots were also present in the soil. Fusarium solani, S. rolfsii, $R$. solani and $P$. myriotylum were consistently isolated from infected root tissues.

The result (Table 3) of the pathogenicity test of all the eight fungal isolates, (Table 3 ), only $P$. myriotylum was pathogenic on cocoyam seedlings. It produced characteristic necrotic roots and chlorotic leaves on the fiveweek old cocoyam 10 days after inoculation. $P$. myriotylum was reisolated from the infected roots of the cocoyam. The observation of the characteristic root rot symptoms and the reisolation of the pathogen from infected cocoyam seedlings showed that $P$. myriotylum incited the root rot disease of cocoyam in this study. The other fungi, particularly those from diseased root tissues may have played a synergistic role in the development of the disease.

Botryodiplodia theobromae, Fusarium solani, Rhizoctonia solani., Fusarium moniliforme, Sclerotium rolfsii, Pythium spp and Phytopthora spp as causal organisms of the cocoyam disease called cocoyam root rot blight complex (Okeke 1982; Arene and Ene 1987). The results of this investigation, however, showed that the cocoyam root rot disease was incited by the organism, Pythium myriotylum and not by a complex of organism as suggested by earlier workers.

\section{REFERENCES}

Adiobo, A; Oumar, O., Perneel M; Zok, S. Hofte, M (2007). Variation of Pythium-induced Cocoyam Root Rot Severity in response to soil type. Soil Biology \& Biochem. 39; 2915-2925.

Agrios, G. N. 2005. Plant Pathology $5^{\text {th }}$ ed. Academic Press, New York pp 923.

Arene, O. B. and Ene. L.S.O. (1987). Advances in Cocoyam Research at National Root Crops Research Institute, Umudike (1972-1986). In proceedings of the $1^{\text {st }}$ National Workshop on cocoyam August 16-21, 1987, Umudike, Nigeria pp 58-71.
Barnett, H. L. and Hunter, B.B. 1987. Illustrated genera of imperfect fungi ( $4^{\text {th }}$ ed.) Macmillan Publishing Co. New York pp. 92-93.

Dutta, A.C. (2005). Botany for Degree students, $6^{\text {th }}$ ed. Oxford University Press, Calcutta 700 pp.

FAO, 2001. Food and Agriculture Organization (FAO) Production Statistics 2005.

FAO, 2004. Food and Agriculture Organization (FAO) Production Statistics 2005.

FAO, 2007. Food and Agriculture Organization (FAO) Production Statistics 2008.

Kay, D. E. 1987. Root Crops- Crop and Product Digest No. 22nd ed. (Revised by E.

G. Gooding) Tropical Development and Research Institute, London pp 380.

Martin, F. N. (1991) Pythium. In Singleton, L; Mihail, J. D. and Rush, C.M. eds). Methods for Research on soil borne phytophathogenic fungi, APS Press Miinesota, USA pp 39-49.

Mbanaso, E. O.; Asumugha, G. N.; Mbanaso, E.N.A.; Ironkwe, A.G. and Ezulike, T. O. 2008. Guide to Cocoyam production. Extension Guide 21, National Root crops research Institute, Umudike - Umuahia pp.8.

NRCRI, 2011. National Root Crops Research Institute, Agro-meteorological report, 2009-2010, Umudike, Umuahia.

Okeke, G. C. 1982. Studies on the Etiology and Symptomalogy of Roots and Storage rot disease of Cocoyam in Nigeria. Beitr. Trop. Landwirrsch Veternamed 203:287-293.

Obi, I. U. (1995). Introduction to Factorial Experiments for Agricultural, Biological and Social Sciences Research. Optimal Computer solutions, Enugu Nigeria. P.23-56.

Pacumbaba, R. R., Wutoh, J. G., Eyango, S. A., Tambong, J. J. and Nyochebeng, I. M., 1992. Isolation and Pathogenicity of Rhizosphere Fungi of Cocoyam in relation to Cocoyam Root Rot Disease. Journal of Phytopathology 135:265273.

Purseglove, J. W. (1972).) Tropical crops: Monocotyledon I. Longmans Ltd., London 548 pp

Tambong, J. J.; Peppe, J. and Hofte, M. 1999. Pathogenicity, Electrophoretic characterization and in planta detection of the Cocoyam Root Rot Disease Pathogen. Pythium mytiotylum. European Journal of plant Pathology 105:597-6087. 
Unamma, RPA., Odurukwe, S. O.., Okereke, H. E., Ene, L.S.O., Okoli, O. O., (1985). Farming Systms in Nigeria; Report of the Bench Survey of the Eastern agricultural zone of Nigeria.

Waterhouse, G. M. and Waterson, J. M. 1966. CMI Description of Pathogenic Fungi and Bacteria Commonwealth Mycological Institute, Kew England.

Wokocha, R. C., Ebenebe, A. C. and Erinle, I. D. (1986) Biological control of the basal stem rot disease of tomato caused by corticium rolfsii (Sacc.) Curzi in Northern Nigeria. Tropical Pest Management 32(1): 35-39.
Wokocha, R.C. and Nwaogu G.A (2008). Comparative toxicity of extracts of three tropical medicinal plants and ridomil (metalaxyl) on Phytophthora palmivora and varietal resistance of cocoa to the Blackpod diseases in Ikwuano Area of Abia State. Nigerian Journal of Botany. 21(2): 428-436.

Umechuruba, C.I. and Elenwo, E.N. (1997). Diagnostic Techniques in Mycology with practical exercises/. Belk Publishers. Port Harcourt, Nigeria. 149 pp. 